\title{
Global longitudinal peak systolic strain is reduced shortly after heart transplantation
}

\section{Željko Baričević* \\ Maja Čikeš \\ Jana Ljubas Maček \\ Boško Skorić \\ Ivan Škorak \\ Hrvoje Jurin \\ Hrvoje Gašparović \\ Bojan Biočina \\ Davor Miličić \\ Jadranka Šeparović \\ Hanževački \\ University of Zagreb \\ School of Medicine \\ University Hospital Centre \\ Zagreb, Zagreb, Croatia}

\section{RECEIVED:}

April 15, 2015

ACCEPTED:

April 20, 2015

\begin{abstract}
KEYWORDS: speckle tracking, myocardial deformation, strain, heart transplantation.
\end{abstract}
CITATION: Cardiol Croat. 2015;10(3-4):57. | DOI: http://dx.doi.org/10.15836/ccar.2015.57

ORCID: Željko Baričević*, http://orcid.org/0000-0002-5420-2324 • Maja Čikeš, http://orcid.org/0000-0002-4772-5549 • Jana Ljubas Maček, http://orcid.org/0000-0001-7171-2206 • Boško Skorić, http://orcid.org/0000-0001-5979-2346• Ivan Škorak, http://orcid.org/0000-0002-4900-4876 • Hrvoje Jurin, http://orcid.org/0000-0002-2599-553X• Hrvoje Gašparović, http://orcid.org/0000-0002-2492-3702 • Bojan Biočina, http://orcid.org/0000-0003-3362-9596 • Davor Miličić, http://orcid.org/0000-0001-9101-1570 • Jadranka Šeparović Hanževački, http://orcid.org/0000-0002-3437-6407

*ADDRESS FOR CORRESPONDENCE: Željko Baričević, Klinički bolnički centar Zagreb, Kišpatićeva 12, HR-10000 Zagreb, Croatia. Phone: +385-98-365-321. E-mail: zbaricev@gmail.com

\section{|IIIIIIIIIIIIIIIIIIIIIIIIIIIIIIIIIIIIIIIIIIIIIIIIIIIIIIIIIIIIIIIIIIIIIIIIIIIIIIIIIIIIIIIIIIIIIIIIIIIIIIIIIIII}

INTRODUCTION: Speckle tracking echocardiography (STE) permits early recognition of myocardial dysfunction. In heart transplant recipients, the reduction in strain has been shown to denote both rejection and vasculopathy ${ }^{1,2}$ However, when compared with control subjects, deformation indices are also reduced in "healthy" HTx recipients ${ }^{3}$ which implies normal LV ejection fraction with no valvular disease, normal ECG, lack of cellular rejection and the absence of vasculopathy. Whether the reduction in strain is a chronic progressive process or the immediate result of transplantation has not been established. Hence, the lack of ST reference values in HTx population is one of the reasons that strain has not been used in Htx follow-up.

PATIENTS AND METHODS: 10 adult Htx patients with 2D STE performed within 14 days post-transplantation were enrolled. Standard first post-transplant check-up included clinical examination, ECG, laboratory tests, endomyocardial biopsy and coronary angiography. The study included "healthy" HTx patients only, with normal LV ejection fraction (EF $\geq 55 \%$ ), normal ECG with sinus rhythm and QRS $<120 \mathrm{~ms}$, lack of cellular rejection (ISHLT

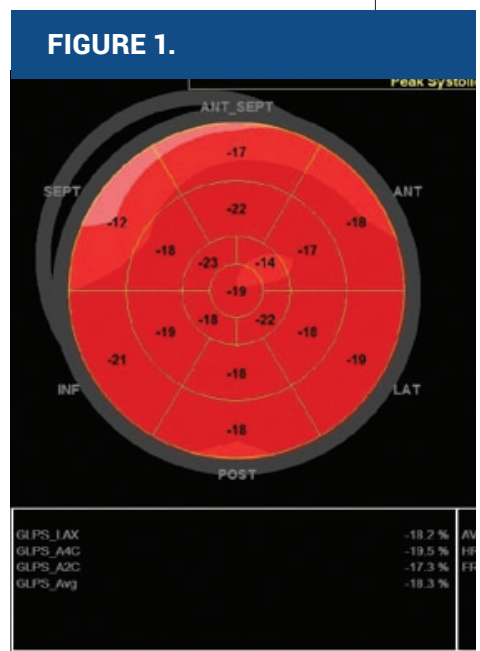

Bull's-eye map showing segmental and global longitudinal peak systolic strain.

\section{FIGURE 2.}

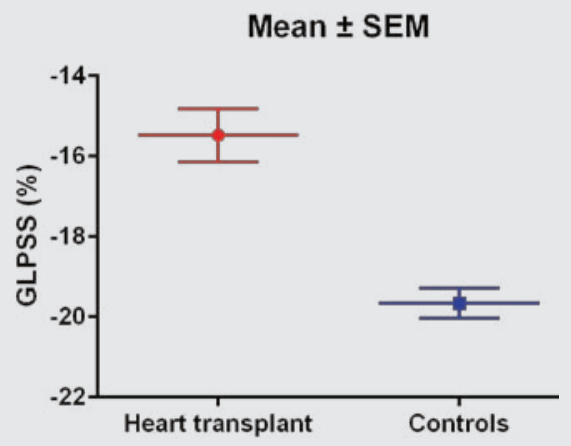

GLPSS in heart transplant recipients vs. normal controls. grade $\leq 1 \mathrm{~B})$ and the absence of coronary disease $(<50 \%$ epicardial artery stenosis). Patients with significant valvular disease, major cardiovascular events or poor quality echocardiographic records were excluded. Echocardiographic images were obtained with acquisition of apical views using high frame rates (50-90 frames/s) for adequate speckle tracking. Global and segmental strain values were determined (Figure 1) and compared to normal subjects' reference values, using data from the literature ${ }^{4}$

RESULTS: Average global longitudinal peak systolic strain (GLPSS) shortly after HTx was significantly reduced when compared with normal subjects' values $(-15.48 \pm 2,08 \%$ vs $-19.7 \% \pm 0,28, p<0,0001)$ (Figure 2 ).

DISCUSSION: The reduced GLPSS values exhibit soon after HTx, which may possibly be caused by prolonged ischemic time, denervation, cardioplegia etc. Whether strain values remain stable over a longer time period has yet to be established. If that case, an early assessment of "normal" strain values in all transplant recipients could serve as a reference, which could allow non-invasive identification of usual post-transplant complications.

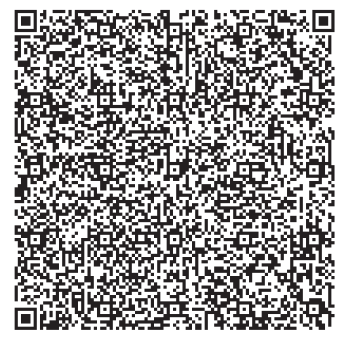

LITERATURE IIIIIIIIIIIIIIIIIIIIIIIIIIIIIIIIIIIIIIIIIIIIIIIIIIIIIIIIIIIIIIIIIIIIIIIIIIIIIIIIIIIIIIIIIIIIIIIIIIIIIIII

1. Dandel M, Wellnhofer E, Hummel M, Meyer R, Lehmkuhl H, Hetzer R. Early detection of left ventricular dysfunction related to transplant coronary artery disease. J Heart Lung Tranplant. 2003;22:1353-64. DOI: http://dx.doi.org/10.1016/S1053-2498(03)00055-X

2. Marciniak A, Eroglu E, Marciniak M, Sirbu C, Herbots L, Droogne W, et al. The potential clinical role of ultrasonic strain and strain rate imaging in diagnosing acute rejection after heart transplantation. Eur J Echocardiogr. 2007;8:213-21. DOI: http://dx.doi.org/10.1016/j.euje.2006.03.014

3. Saleh HK, Villarraga HR, Kane GC, Pereira NL, Raichlin E, Yu Y, et al. Normal left ventricular mechanical function and synchrony values by speckletracking echocardiography in the transplanted heart with normal ejection fraction. J Heart Lung Transplant. 2011;30(6):652-8. DOI: http://dx.doi.org/10.1016/j.healun.2010.12.004

4. Yingchoncharoen T, Agarwal S, Popović ZB, Marwick TH. Normal ranges of left ventricular strain: a meta-analysis. J Am Soc Echocardiogr. 2013;26(2):185-91. DOI: http://dx.doi.org/10.1016/j.echo.2012.10.008 